\title{
China's global engagement to fight the novel coronavirus pandemic
}

\author{
Wei Song (1)
}

\begin{abstract}
The world is confronted by the current pandemic of coronavirus disease 2019 (COVID-19), which is a common threat to the whole of humanity. In the process of fighting COVID-19 domestically, China had attached great importance to international cooperation, such as the sharing of information on the pandemic with the international community, providing bilateral and multilateral assistance to other affected countries, etc. However, due to the severity of this pandemic, global solidarity is necessary to conquer it, and to improve global public health governance.
\end{abstract}

Keywords: China, Official development aid, COVID-19, Pandemic

\section{Background}

The novel coronavirus disease (COVID-19) first broke out in Wuhan in December 2019. Facing this unknown infectious disease, the Chinese government took preventative measures immediately, including implementing a nationwide quarantine, offering medical support and mobilizing resources from all over the country, enhancing public education, strengthening individual protection, medical isolation, controlling population mobility, and reducing gatherings [1]. Furthermore, the government quickly formulated the Law on 'Punishing Legally the Crimes of Violating the Prevention of Novel Coronavirus Infected Pneumonia' [2]. These measures are not only directly associated with China's overall containment of the epidemic [3], but also contribute valuable experience for the international community in its fight against it. And during this process, China has received material assistance and moral support from many countries, such as Iran, Israel, Pakistan, South Korea, Japan, Cuba, Russia and some European countries. In return, China also actively provided assistance to the international community, including medical materials and

Correspondence: songwei@caitec.org.cn

CAITEC International Development Cooperation Institute, No. 28 Donghouxiang, Anwai, Beijing 100710, China knowledge-sharing. China's commitment has been highly recognized and appreciated by many countries, such as Italy and Serbia.

Moreover, the emergence of COVID-19 coincided with the largest annual human migration in the world, i.e., the Spring Festival travel season, which brought about a rapid national and global spread of the virus [4]. The first 100 thousand cases took 67 days, the second 100 thousand cases took 11 days, and the third 100 thousand cases took only 4 days. The pandemic seriously has threatened the lives and health of people all over the world, exerting a deep impact on the global political, economic and social map. Against this backdrop, the purpose of this commentary is to analyze China's global engagement in the fight against COVID-19, which not only is conducive to a more effective fight against the pandemic, but also illuminates the improvement in global public governance.

\section{China's global engagement}

In the era of globalization, the interests of human societies are highly integrated. As Chinese President Xi Jinping put it, viruses don't respect borders, and pandemics don't respect races. The outbreak of COVID19 has once again demonstrated that mankind is a community of shared destiny. China has continued to firmly adhere to the concept of a community of

(c) The Author(s). 2020 Open Access This article is licensed under a Creative Commons Attribution 4.0 International License, which permits use, sharing, adaptation, distribution and reproduction in any medium or format, as long as you give appropriate credit to the original author(s) and the source, provide a link to the Creative Commons licence, and indicate if changes were made. The images or other third party material in this article are included in the article's Creative Commons licence, unless indicated otherwise in a credit line to the material. If material is not included in the article's Creative Commons licence and your intended use is not permitted by statutory regulation or exceeds the permitted use, you will need to obtain permission directly from the copyright holder. To view a copy of this licence, visit http://creativecommons.org/licenses/by/4.0/. 
shared destiny, working together with people of all countries to strive for a final victory in the fight.

\section{Exchanging views at high level}

Chinese leaders have attached great importance to international cooperation concerning anti-pandemic policy, even as they fight COVID-19 domestically. Up to mid-May, President Xi Jinping had striven to exchange views with nearly 50 foreign leaders and heads of international organizations in 2 months through "telephone diplomacy" or face to face discussion. On March 26, he actively participated in the G20 special summit on the epidemic, pointing out that the international community should step up its efforts to effectively carry out joint prevention and control measures.. In addition, President Xi Jinping declared a package of humanitarian and development assistance to the Least Developed Countries and other countries seriously infected at the opening ceremony of the World Health Organization's 73rd World Health Assembly.

\section{Knowledge-sharing}

China actively and generously shared information on the pandemic with the international community. Thanks to China's advantage in information communications technology and in innovative technology enterprises, China developed a relatively complete public online reporting system within a very short time [5]. China built an academic sharing platform and a communication mechanism to share genomic information and promote capacity building. In point of fact, it is the right choice to carry out international cooperation and concentrate human wisdom on vaccine research and development, as challenges abound and uncertainties lie ahead. Now China is endeavoring to develop vaccines following five technological routes: inactivated vaccines, recombinant protein vaccines, live attenuated influenza vaccines, adenovirus vaccines, and nucleic acid-based vaccines, and all of which involve international cooperation and are open to the international community. With knowledge sharing, an increasing number of countries switched to more stringent public health strategies including city lockdowns and mandatory quarantines [6]. And lockdown has now been implemented in Europe [7]. In addition, universities and hospitals actively participated in experience sharing. The Chinese diaspora, especially students overseas, was also a crucial channel for sharing and spreading related experiences, as they acquired relevant information on prevention and control measures from home and then shared it with people around them.

\section{Bilateral assistance}

China actively provided assistance to other affected countries, meanwhile fighting against the domestic epidemic, including providing funds and medical materials, sending medical teams and so forth. Although the masks and medicines in China were at the time in short supply, the Chinese government put a premium on supporting the export of medical materials, and welcomed export enterprises to organize the external supply of masks and other medical materials, so as to make due contributions to global epidemic prevention in a practical manner. Table 1 reflects the bilateral support China has provided to global society.

\section{Multilateral assistance}

China has actively participated in international cooperation through multilateral channels: it has contributed to the World Health Organization, the United Nations, and the African Union; meanwhile, China has also donated $\$ 55$ million to the WHO. Furthermore, at the opening ceremony of the video conference of the 73rd Assembly of the WHO, China's President Xi Jinping promised to provide $\$ 2$ billion within 2 years to support countries affected by the pandemic, especially developing countries, in order to help them recover economically and socially. Finally, once the vaccine is developed, China has

Table 1 China's Official Development Assistance to Global AntiPandemic Efforts

\begin{tabular}{|c|c|}
\hline $\begin{array}{l}\text { Material- } \\
\text { supplying }\end{array}$ & $\begin{array}{l}\text { Assisted the WHO in purchasing personal protective } \\
\text { equipment and establishing reserve centers of supplies } \\
\text { in China; } \\
\text { Participated in the WHO's "Access to COVID-19 Tools } \\
\text { (act) Accelerator" initiative, aiming to speed up the } \\
\text { development, production and equitable distribution } \\
\text { of new tools; } \\
\text { Exported protective materials to } 200 \text { countries and } \\
\text { regions, among which there were more than } \\
70.6 \text { billion masks, } 340 \text { million protective suits, } \\
115 \text { million pairs of goggles, } 96,700 \text { ventilators, } \\
225 \text { million test kits, and } 40.29 \text { million infrared } \\
\text { thermometers. }\end{array}$ \\
\hline Cash support & $\begin{array}{l}\text { Two batches of cash support totaling } \$ 50 \text { million } \\
\text { to the WHO; } \\
\text { Helped WHO's COVID-19 Solidarity Response } \\
\text { Fund to raise funds in China; } \$ 2 \text { billion to the } \\
\text { international community within } 2 \text { years; }\end{array}$ \\
\hline $\begin{array}{l}\text { Capacity } \\
\text { building }\end{array}$ & $\begin{array}{l}29 \text { medical expert teams were sent to } 27 \text { countries; } \\
\text { Medical teams stationed in } 56 \text { countries supported the } \\
\text { local fight, and provided counseling and health } \\
\text { information to local people and overseas Chinese, } \\
\text { organizing over } 400 \text { online and offline training sessions; }\end{array}$ \\
\hline
\end{tabular}

Statistics at: Full Text: Fighting COVID-19: China in Action, The State Council Information Office of the People's Republic of China, June 2020. Available at: http://www.scio.gov.cn/zfbps/32832/Document/1681809/1681809.htm President Xi Jinping's speech at the opening ceremony of the World Health Organization's 73rd World Health Assembly, Xinhua Net, May 18, 2020. Available at: http://m.xinhuanet.com/2020-05/18/c_1126001593.htm 
committed to provide it to the international community as a global public product. Of note, the World Food Program (WFP), with the support of the Chinese government, established the UN Global Humanitarian Response hub in China, and the first batch of antipandemic supplies arrived in the warehouse hub in Guangzhou in April 30, and was transported to other emergency points identified by the United Nations or directly to the countries and regions affected by COVID-19. With its leading manufacturing industry, complete supply chain, and technological innovation, China holds unique advantages in setting up an emergency hub.The above Table 1 also reflects the multilateral support China has provided to the global society.

\section{Public-private partnership}

China is striving to mobilize various institutions and parties to support the global anti-pandemic efforts by actively promoting the Public-Private Partnership modality. In March, under the guidance of the International Liaison Department of the Central Committee of the $\mathrm{CPC}$, the China NGO Network for International Exchanges (CNIE), China's largest association of international exchange-oriented social organizations, launched the joint action "Silk Road and One Family" to fight against the pandemic, calling on non-governmental actors to assist countries in need. Under the framework of the joint action, China's non-governmental forces have carried out various forms of anti-pandemic cooperation with more than 50 countries, including materialsupplying, experience-sharing and volunteer-dispatching, with this foreign assistance volume totaling more than 25 million U.S. dollars.

\section{Future directions}

Given the existential challenge posed by COVID-19, international cooperation is imperative to our very survival as a species. As the first priority lies in addressing the humanitarian challenge through proper preventive measures to stop its spread, as well as finding curative measures to develop a vaccine [8], it is essential to strengthen global solidarity to cooperate in a bid to conquer the pandemic, and to improve global public health governance. Although data shows that China has brought the infection rate under control, epidemiologists have warned that the pandemic may bounce back in a context where officials relax restrictions and more people return to work. And further efforts are required to determine how to strike a balance between the expected positive effect on public health and the negative impact on freedom of movement, the economy, and society at large [9]. Therefore, cooperation between major countries, especially China and the other major world power, the United States, is still the fundamental way to effectively fight against COVID-19.

As China's Foreign Minister Wang Yi put it, COVID19 is a common enemy for both China and United States; therefore, mutual help and support should be a common goal of the two peoples and governments. And some governments at the state level and NGOs from the United States are also actively promoting Sino-US cooperation at present. Given the structure of the current world system it is impossible for single countries to fight COVID-19 by themselves. COVID-19 will test our capacity as a species to exert effective global health governance.

\section{Abbreviations}

COVID-19: Coronavirus disease 2019; BRI: Belt and Road Initiative; WHO: World Health Organization

\section{Acknowledgements}

I appreciate Dr. Li Hao for his professional editing for this manuscript, which substantially improves the quality of this manuscript.

\section{Author's contributions}

I am the sole contributor to this article. The author(s) read and approved the final manuscript.

\section{Authors' information}

SONG Wei is the Deputy Director of the institute of International Development Cooperation in the Chinese Academy of International Trade and Economic Cooperation affiliated with China's Ministry of Commerce. She has been a Fulbright visiting scholar at Columbia University, USA.

\section{Funding}

This study received no funding.

Ethics approval and consent to participate

Not applicable.

Consent for publication

Not applicable.

\section{Competing interests}

The authors declare no competing interests associated with this study.

Received: 2 July 2020 Accepted: 10 September 2020

Published online: 16 October 2020

\section{References}

1. Qiu J, Shen B, Zhao M, et al. A nationwide survey of psychological distress among Chinese people in the COVID-19 epidemic: implications and policy recommendations. Gen Psychiatry. 2020. https://doi.org/10.1136/gpsych-202 0-100213.

2. $\mathrm{Li} \mathrm{H}, \mathrm{Hu} \mathrm{M}$, Liu S. The need to improve the laws and regulations relevant to the outbreak of COVID-19: what might be learned from China? Viewpoints. 2020;10(1):1-4.

3. Tian H, Liu Y, Li Y, et al. An investigation of transmission control measures during the first 50 days of the COVID-19 epidemic in China. Science. 2020; 368:638-42

4. Lin Q, Zhao S, Gao D, et al. A conceptual model for the coronavirus disease 2019 (COVID-19) outbreak in Wuhan, China with individual reaction and governmental action. Int J Infect Dis. 2020;93:211-6.

5. Li $\mathrm{H}$, Chen $\mathrm{X}$, Huang $\mathrm{H}$. The novel coronavirus outbreak: what can be learned from China in public reporting? Glob Health Res Policy. 2020;5:9. https://doi.org/10.1186/s41256-020-00140-9.

6. Qiu Y, Chen X, Shi W. Impacts of social and economic factors on the transmission of coronavirus disease 2019 (COVID-19) in China. J Popul Econ. 2020. https://doi.org/10.1007/s00148-020-00778-2. 
7. Lau H, Khosrawipour V, Kocbach P, et al. The positive impact of lockdown in Wuhan on containing the COVID-19 outbreak in China. J Travel Med. 2020; 27(3):1-7. https://doi.org/10.1093/jtm/taaa037.

8. Hua J, Shaw R. Corona virus (COVID-19) "Infodemic" and emerging issues through a data Lens: the case of China. Int J Environ Res Public Health. 2020;17:2309. https://doi.org/10.3390/ijerph17072309.

9. Kraeme MUG, Yang C-H, Gutierrez B, et al. The effect of human mobility and control measures on the COVID-19 epidemic in China. Science. 2020;368: 493-7.

Ready to submit your research? Choose BMC and benefit from:

- fast, convenient online submission

- thorough peer review by experienced researchers in your field

- rapid publication on acceptance

- support for research data, including large and complex data types

- gold Open Access which fosters wider collaboration and increased citations

- maximum visibility for your research: over $100 \mathrm{M}$ website views per year

At $B M C$, research is always in progress.

Learn more biomedcentral.com/submissions 